\title{
The Effect of Location, Product Diversity, and Service Quality of Members Satisfaction at BMT Muamalah Kutoanyar Tulungagung and BMT Nusantara Umat Mandiri Kalidawir Tulungagung
}

\author{
Bintari Sukma Ningrum ${ }^{1 *}$, Citra Mulya Sari2 \\ ${ }^{1}$ Department of Islamic Banking, Faculty of Economic and Islamic Business, UIN Sayyid Ali \\ Rahmatullah Tulungagung, Indonesia \\ ${ }^{2}$ Department of Islamic Economics, Faculty of Economic and Islamic Business, UIN Sayyid Ali \\ Rahmatullah Tulungagung, Indonesia
}

\begin{abstract}
This Research is motivated by increansingly fierce competition in Islamic financial institutions, especially BMT. The success or progress of BMT can not be separated from members satisfaction. The way to create members satisfaction is by choosing the right institution location, providing a variety of products to suit the needs of members, and providing good service that can fulfill the expectations of members. Members who feel satisfied will have a good impact on BMT. This research uses a quantitative approach and associative research of type. Sampling with propability sampling technique and sampling method with simple random sampling. Total sample in this research were 98 respondents from BMT Muamalah Kutoanyar Tulungagung and 89 respondents from BMT NUsantara UMAT MANDIRI Kalidawir Tulungagung. The data collection method used primary data which was analyzed using multiple linear regression. The result of this research showed: 1) Location has a positive and significant effect on members satisfaction. 2) Product diversity has a positive and significant effect on members satisfaction. 3) Service quality has a positive and significant effect on members satisfaction. 4) Location, product diversity, and service quality simultaneously have a positive and significant effect on member satisfaction.
\end{abstract}

\section{Introduction}

In an increasingly tight business world, business actors are required to create competitive advantages in order to win the competitive market. Bank and non-bank financial institutions based on sharia and conventional compete for market attention, because selling their products in the form of services is certainly not easy to gain competitive advantage. Indonesia is a

\footnotetext{
*Corresponding author: citramulyasari007@gmail.com
} 


\section{$A \overline{I E B} \quad$ Annual International Conference \\ on Islamic Economics and Business, 2021}

country that has the largest Muslim population in the world. This is a great opportunity for the development of Islamic financial institutions. Along with these developments, it certainly provides many options for members or customers to use Islamic financial institution products with the profit-sharing method. Sharia bank financial institutions consist of Sharia Commercial Banks and Sharia People's Financing Banks, while non-bank sharia financial institutions are Baitul Maal wa Tamwil (BMT).

Baitul Maal wa Tamwil (BMT) is an institution consisting of two terms, namely baitul maal and baitul tamwil. Baitul Maal activities are more directed at non-profit businesses, such as infaq, alms and zakat. Meanwhile, Baitul Tamwil's activities are aimed at collecting and distributing commercial funds. Baitul Maal Wa Tamwil (BMT) is a non-governmental organization which means the community that establishes and develops it. The purpose of establishing BMT is also so that the quality of economic business increases for the welfare of the community (Ridwan, 2004).

The success or progress of a BMT cannot be separated from member satisfaction. Member satisfaction is the key to the success of a business carried out by every BMT because BMT has many products that are marketed, so many efforts must be made by BMT to provide satisfaction to its members. Member satisfaction is a person's feeling of pleasure or disappointment that arises after comparing the performance (results) of the product that is thought to the expected performance (Rizka and Aris, 2019). The factors that influence member/consumer satisfaction according to Tjiptono and Candra in Iga Mawarni (2018) are product, price, promotion, location, employee service, facilities, and atmosphere. If it is realized, it is certain that members will feel satisfied and have a good impact on the progress of BMT.

The right location of the institution is one of the factors of member satisfaction. If there is an error in choosing a location or place, it will have a major impact on the viability of the institution on an ongoing basis. Location also plays a role in determining the level of business success. The strategic location makes it easier for members or customers to access the road to the office. So it takes a location that is easily accessible by members or customers (Lidia and Euis, 2018).

To increase member satisfaction, apart from an easy-to-reach location, various products that match the needs of the market can provide maximum satisfaction to members. Consumers or members tend to choose institutions or BMTs that provide a wide selection of products. A wide selection of products can be tailored to the needs of consumers/members. Members/consumers will be satisfied if the number and types of products offered in a place vary according to what consumers need and also pay attention to current market demands (Rohmawati, 2018).

In addition, the quality of services provided by the institution or BMT is one of the factors that affect satisfaction. Fulfillment of consumer expectations is the goal of the quality of service provided by a company, while consumer expectations are not always the same. Consumers always judge a service they receive compared to what they expect or want (Wahab, 2017).

By understanding the needs and measuring satisfaction with the location, the variety of products and the quality of service provided is one of the important things to be done by BMT Muamalah Kutoanyar Tulungagung and BMT NUsantara UMAT MANDIRI Kalidawir Tulungagung. By knowing the level of member satisfaction, BMT Muamalah Kutoanyar Tulungagung and BMT NUsantara UMAT MANDIRI Kalidawir Tulungagung will know their position in business competition. Furthermore, it will be easier to take policies to implement strategies to increase member satisfaction through location, variety of products offered, and quality of service provided. These three factors are things that can determine member satisfaction. Member satisfaction is very important because members are satisfied 


\section{$A \mathrm{I} \overline{I E B}$ Annual International Conference \\ on Islamic Economics and Business, 2021}

with the location, product diversity, and service quality of the BMT, the continuity of the BMT will run well.

\section{Theories}

The location is a place for buying and selling bank products for the community and a banking control center (Kasmir, 2005).

Product Diversity is a group of all goods and products that a particular seller offers to buyers. Sales volume is strongly influenced by consumer interest in various products (Indrasari, 2019).

According to Parasuraman in Lupiyoadi (2001) suggests that: service quality is how far the difference between reality and customer expectations for the services they receive/receive.

According to Kotler in Conny Sondakh (2014) customer satisfaction is a consumer's expectation that is fulfilled with the level of perceived performance that the product will meet.

\section{Research Method}

Quantitative research approach with associative research type. The population in this study were members at BMT Muamalah Kutoanyar Tulungagung as many as 4538 and at BMT NUsantara UMAT MANDIRI Kalidawir Tulungagung as many as 773 . The total population of BMT Muamalah Kutoanyar Tulungagung and BMT NUsantara UMAT MANDIRI Kalidawir Tulungagung was 5,311. The sampling method is using probability sampling technique and the sampling method is simple random sampling using the slovin formula. The number of samples in this study were 98 respondents from BMT Muamalah Kutoanyar Tulungagung and 89 respondents from BMT NUsantara UMAT MANDIRI Kalidawir Tulungagung. Data collection method using primary data. Research independent variables: Location (X1), Product Diversity (X2), and Service Quality (X3). Dependent variable: Member Satisfaction (Y). The measurement scale uses a Likert scale and data analysis techniques using multiple linear regression.

\section{Research and Discussion}

\subsection{Validity Test}

Table 1. BMT Muamalah Kutoanyar Tulungagung Validity Test Results

\begin{tabular}{|c|c|c|c|c|}
\hline Variable & $\begin{array}{c}\text { Question } \\
\text { Items }\end{array}$ & r-count & r-table & Description \\
\hline \multirow{3}{*}{$\begin{array}{c}\text { Location } \\
\text { (X1) }\end{array}$} & Item 1 & 0,622 & 0,1986 & Valid \\
\cline { 2 - 5 } & Item 2 & 0,685 & 0,1986 & Valid \\
\cline { 2 - 5 } & Item 3 & 0,583 & 0,1986 & Valid \\
\cline { 2 - 5 } & Item 4 & 0,594 & 0,1986 & Valid \\
\cline { 2 - 5 } & Item 5 & 0,664 & 0,1986 & Valid \\
\hline Product & Item 1 & 0,693 & 0,1986 & Valid \\
\cline { 2 - 5 } Diversity \\
(X2) & Item 2 & 0,707 & 0,1986 & Valid \\
\cline { 2 - 5 } & Item 3 & 0,746 & 0,1986 & Valid \\
\cline { 2 - 5 } & Item 4 & 0,808 & 0,1986 & Valid \\
\cline { 2 - 5 } & Item 5 & 0,832 & 0,1986 & Valid \\
\cline { 2 - 5 } & Item 6 & 0,799 & 0,1986 & Valid \\
\hline
\end{tabular}




\begin{tabular}{|c|c|c|c|c|}
\hline & Item 7 & 0,748 & 0,1986 & Valid \\
\cline { 2 - 5 } & Item 8 & 0,723 & 0,1986 & Valid \\
\hline Service \\
Quality (X3) & Item 1 & 0,926 & 0,1986 & Valid \\
\cline { 2 - 5 } & Item 2 & 0,734 & 0,1986 & Valid \\
\cline { 2 - 5 } & Item 3 & 0,926 & 0,1986 & Valid \\
\cline { 2 - 5 } & Item 4 & 0,733 & 0,1986 & Valid \\
\cline { 2 - 5 } & Item 5 & 0,914 & 0,1986 & Valid \\
\hline Member & Item 1 & 0,696 & 0,1986 & Valid \\
\cline { 2 - 5 } Satisfaction \\
\cline { 2 - 5 } (Y)
\end{tabular}

Source: SPSS 23 results data, 2021

Based on the table above, all questionnaire items are valid because the value of rcount $>$ rtable, which means $r$ count $>0,1866$. In this study, it means that all statement items or questionnaire indicators meet the validity requirements and are declared valid.

Table 2. BMT NUsantara UMAT MANDIRI Kalidawir Tulungagung Validity Test Results

\begin{tabular}{|c|c|c|c|c|}
\hline Variable & $\begin{array}{c}\text { Question } \\
\text { Items }\end{array}$ & r-count & r-table & Description \\
\hline \multirow{4}{*}{ Location (X1) } & Item 1 & 0,504 & 0,2084 & Valid \\
\cline { 2 - 5 } & Item 2 & 0,651 & 0,2084 & Valid \\
\cline { 2 - 5 } & Item 3 & 0,637 & 0,2084 & Valid \\
\cline { 2 - 5 } & Item 4 & 0,670 & 0,2084 & Valid \\
\cline { 2 - 5 } & Item 5 & 0,675 & 0,2084 & Valid \\
\cline { 2 - 5 } & Item 1 & 0,901 & 0,2084 & Valid \\
\cline { 2 - 5 } & Item 2 & 0,816 & 0,2084 & Valid \\
\cline { 2 - 5 } Product & Item 3 & 0,612 & 0,2084 & Valid \\
\cline { 2 - 5 } (X2) & Item 4 & 0,797 & 0,2084 & Valid \\
\cline { 2 - 5 } & Item 5 & 0,686 & 0,2084 & Valid \\
\cline { 2 - 5 } & Item 6 & 0,861 & 0,2084 & Valid \\
\cline { 2 - 5 } & Item 7 & 0,897 & 0,2084 & Valid \\
\cline { 2 - 5 } & Item 8 & 0,888 & 0,2084 & Valid \\
\cline { 2 - 5 } & Item 1 & 0,646 & 0,2084 & Valid \\
\cline { 2 - 5 } Service & Item 2 & 0,458 & 0,2084 & Valid \\
\cline { 2 - 5 } & Item 3 & 0,733 & 0,2084 & Valid \\
\cline { 2 - 5 } & Item 4 & 0,659 & 0,2084 & Valid \\
\cline { 2 - 5 } & Item 5 & 0,767 & 0,2084 & Valid \\
\cline { 2 - 5 } & Item 1 & 0,671 & 0,2084 & Valid \\
\cline { 2 - 5 } & Item 2 & 0,644 & 0,2084 & Valid \\
\cline { 2 - 5 } & Item 3 & 0,558 & 0,2084 & Valid \\
\cline { 2 - 5 } Member & Item 4 & 0,669 & 0,2084 & Valid \\
\cline { 2 - 5 } Satisfaction \\
(Y) & Item 5 & 0,616 & 0,2084 & Valid \\
\hline
\end{tabular}

Source: SPSS 23 results data, 2021

Based on the table above, all questionnaire items are valid because the value of rcount $>$ rtable, which means $\mathrm{r}$ count $>0,2084$. In this study, it means that all statement items or questionnaire indicators meet the validity requirements and are declared valid. 


\subsection{Reliability Test}

Table 3. BMT Muamalah Kutoanyar Tulungagung Reliability Test Results

\begin{tabular}{|c|c|c|}
\hline Variable & $\begin{array}{c}\text { Cronbach's } \\
\text { Alpha }\end{array}$ & Description \\
\hline Location (X1) & 0,619 & Reliable \\
\hline Product Diversity (X2) & 0,891 & Very Reliable \\
\hline Service Quality (X3) & 0,905 & Very Reliable \\
\hline Member Satisfaction (Y) & 0,708 & Reliable \\
\hline
\end{tabular}

Source: SPSS 23 results data, 2021

Based on the table above, the value of Cronbach's Alpha for the location variable (X1) and the member satisfaction variable (Y) obtained a value of $>0,61$ which means that the statement from this research questionnaire is considered reliable. While the product diversity variable (X2) and service quality variable (X3) obtained a value of $>0,81$ which means that the statement from this research questionnaire is considered very reliable.

Table 4. BMT NUsantara UMAT MANDIRI Kalidawir Tulungagung Reliability Test Results

\begin{tabular}{|c|c|c|}
\hline Variable & $\begin{array}{c}\text { Cronbach's } \\
\text { Alpha }\end{array}$ & Description \\
\hline Location (X1) & 0,616 & Reliable \\
\hline Product Diversity (X2) & 0,925 & Very Reliable \\
\hline Service Quality (X3) & 0,669 & Reliable \\
\hline Member Satisfaction (Y) & 0,625 & Reliable \\
\hline
\end{tabular}

Source: SPSS 23 results data, 2021

Based on the table above, the value of Cronbach's Alpha for the location variable (X1), service quality variable (X3), and member satisfaction variable $(\mathrm{Y})$ obtained a value of $>0,61$ which means that the statement from this research questionnaire is considered reliable. While the product diversity variable (X2) obtained a value of $>0,81$ which means that the statement from this research questionnaire is considered very reliable.

\subsection{Classic Assumption Test}

\subsubsection{Normality Test}

Table 5. BMT Muamalah Kutoanyar Tulungagung Kolmogorov Smirnov Normality Test Results

One-Sample Kolmogorov-Smirnov Test

\begin{tabular}{|ll|r|}
\hline & & $\begin{array}{c}\text { Unstandardized } \\
\text { Residual }\end{array}$ \\
\hline Normal Parameters & \\
& & Mean \\
Most Extreme Differences & Std. Deviation & .0000000 \\
& Absolute & 1.50472644 \\
& Positive & .099 \\
Kolmogorov-Smirnov Z & Negative & .099 \\
Asymp. Sig. (2-tailed) & & -.053 \\
\end{tabular}

a. Test distribution is Normal.

Source: SPSS 23 results data, 2021 


\section{$A \mathrm{IC} \overline{I E B}$ Annual International Conference \\ on Islamic Economics and Business, 2021}

From the results of the normality test using the One Sample Kolmogorov-Smirnov, the Asymp value is obtained. Sig. (2-tailed) of 0,292 > 0,05 which means the residual value is normally distributed or meets the assumption of normality.

Table 6. BMT NUsantara UMAT MANDIRI Kalidawir Tulungagung Kolmogorov Smirnov Normality Test Results

One-Sample Kolmogorov-Smirnov Test

\begin{tabular}{|c|c|c|}
\hline & & $\begin{array}{c}\text { Unstandardized } \\
\text { Residual }\end{array}$ \\
\hline $\mathrm{N}$ & & 89 \\
\hline \multirow{2}{*}{ Normal Parameters ${ }^{a}$} & Mean & .0000000 \\
\hline & Std. Deviation & 1.25033236 \\
\hline \multirow[t]{3}{*}{ Most Extreme Differences } & Absolute & .093 \\
\hline & Positive & .093 \\
\hline & Negative & -.056 \\
\hline Kolmogorov-Smirnov Z & & .878 \\
\hline Asymp. Sig. (2-tailed) & & .424 \\
\hline
\end{tabular}

a. Test distribution is Normal.

Source: SPSS 23 results data, 2021

From the results of the normality test using the One-Sample Kolmogrov-Smirnov, the Asymp value is obtained. Sig. (2-tailed) of 0,424 >0,05 which means the residual value is normally distributed or meets the assumption of normality.

\subsubsection{Multicollinearity Test}

Table 7. BMT Muamalah Kutoanyar Tulungagung Multicollinearity Test Results

\section{Coefficients $^{\mathrm{a}}$}

\begin{tabular}{|ll|r|c|}
\hline \multirow{2}{*}{ Model } & \multicolumn{2}{|c|}{ Collinearity Statistics } \\
\cline { 3 - 4 } & Tolerance & \multicolumn{1}{c|}{ VIF } \\
\hline 1 & (Constant) & .986 & \\
& LOKASI & .981 & 1.014 \\
& KERAGAMAN PRODUK & 1.019 \\
& KUALITAS PELAYANAN & .981 & 1.020 \\
\hline
\end{tabular}

a. Dependent Variable: KEPUASAN ANGGOTA

Source: SPSS 23 results data, 2021

Based on the table above, it can be seen that the Tolerance value for the location variable $(\mathrm{X} 1)$ is $0,986>0,10$, the product diversity variable $(\mathrm{X} 2)$ is $0,981>0,10$, and the service quality variable (X3) is $0,981>0,10$. While the VIF value of the location variable (X1) is $1,014<10,00$, the product diversity variable (X2) is $1,019<10,00$, and the service quality variable $(\mathrm{X} 3)$ is $1,020<10,00$. The results of the Tolerance and VIF values are all free from the classical assumption of multicollinearity. 


\section{$A \mathrm{IC} \overline{I E B}$ Annual International Conference \\ on Islamic Economics and Business, 2021}

Table 8. BMT NUsantara UMAT MANDIRI Kalidawir Tulungagung Multicollinearity Test Results Coefficients $^{\mathrm{a}}$

\begin{tabular}{|ll|r|c|}
\hline \multirow{2}{*}{ Model } & \multicolumn{2}{|c|}{ Collinearity Statistics } \\
\cline { 3 - 4 } & & Tolerance & \multicolumn{1}{c|}{ VIF } \\
\hline 1 & (Constant) & .993 & \\
& LOKASI & .998 & 1.007 \\
& KERAGAMAN PRODUK & 1.002 \\
& KUALITAS PELAYANAN & .994 & 1.006 \\
\hline
\end{tabular}

a. Dependent Variable: KEPUASAN ANGGOTA

Source: SPSS 23 results data, 2021

Based on the table above, it can be seen that the Tolerance value for the location variable $(\mathrm{X} 1)$ is $0,993>0,10$, the product diversity variable $(\mathrm{X} 2)$ is $0,998>0,10$, and the service quality variable (X3) is $0,994>0,10$. Meanwhile, the VIF value of the location variable (X1) is $1,007<10,00$, the product diversity variable (X2) is $1,002<10,00$, and the service quality variable (X3) is $1,006<10,00$. The results of the Tolerance and VIF values are all free from the classical assumption of multicollinearity.

\subsubsection{Heteroscedasticity Test}

Scatterplot

Dependent Variable: KEPUASAN ANGGOTA

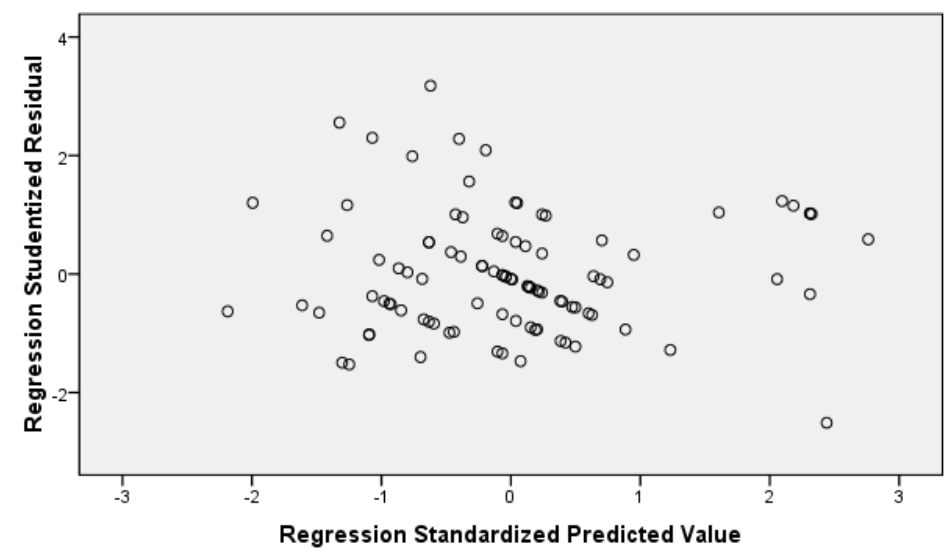

Figure 1. BMT Muamalah Kutoanyar Tulungagung Heteroscedasticity Test Results 


\section{$A I \overline{I E B}$ Annual International Conference \\ on Islamic Economics and Business, 2021}

Scatterplot

Dependent Variable: KEPUASAN ANGGOTA

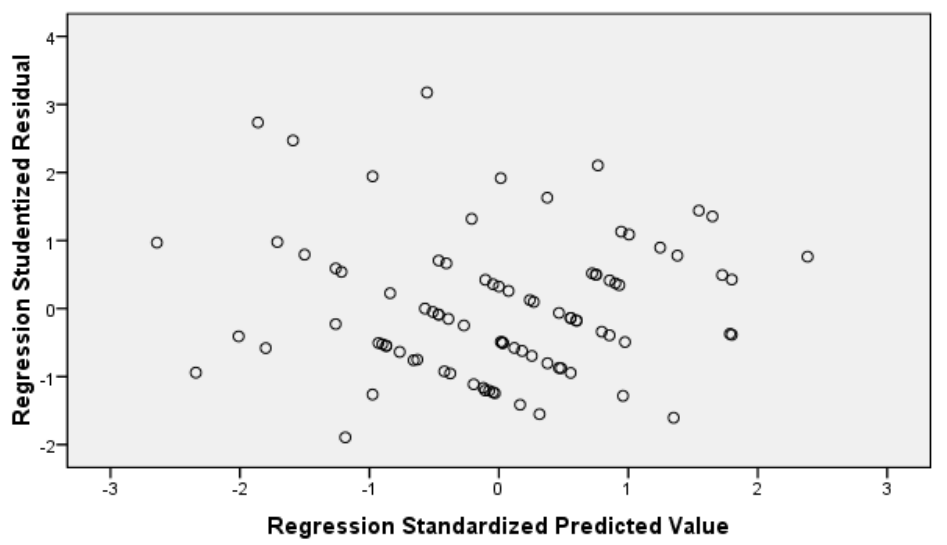

Figure 2. BMT NUsantara UMAT MANDIRI Kalidawir Tulungagung Heteroscedasticity Test Results

Based on the results of the above test using a scatterplot graph, it shows that the two images above do not form a certain clear pattern and the points spread above and below the number 0 on the $\mathrm{Y}$ axis. So it can be concluded that there is no heteroscedasticity in the multiple linear regression model in this research.

\subsection{Multiple Linear Regression Test}

Table 9. BMT Muamalah Kutoanyar Tulungagung Multiple Linear Regression Test Results

\section{Coefficients $^{a}$}

\begin{tabular}{|c|c|c|c|c|c|c|}
\hline & & \multicolumn{2}{|c|}{$\begin{array}{l}\text { Unstandardized } \\
\text { Coefficients }\end{array}$} & $\begin{array}{c}\text { Standardized } \\
\text { Coefficients } \\
\end{array}$ & \multirow[b]{2}{*}{$\mathrm{t}$} & \multirow[b]{2}{*}{ Sig. } \\
\hline \multicolumn{2}{|c|}{ Model } & B & Std. Error & Beta & & \\
\hline \multirow[t]{4}{*}{1} & (Constant) & 3.050 & 2.377 & & 1.284 & .202 \\
\hline & LOKASI & .149 & .072 & .154 & 2.068 & .041 \\
\hline & $\begin{array}{l}\text { KERAGAMAN } \\
\text { PRODUK }\end{array}$ & .094 & .042 & .166 & 2.223 & .029 \\
\hline & $\begin{array}{l}\text { KUALITAS } \\
\text { PELAYANAN }\end{array}$ & .545 & .062 & .661 & 8.847 & .000 \\
\hline
\end{tabular}

a. Dependent Variable: KEPUASAN

ANGGOTA

Source: SPSS 23 results data, 2021

In this study, the multiple linear regression equation from the regression results obtained is as follows:

$\mathrm{Y}=3,050+0,149 \mathrm{X} 1+0,094 \mathrm{X} 2+0,545 \mathrm{X} 3$

Based on the above equation it can be concluded that:

a. The value of a (constant) of 3,050 states that if the variables of location, product diversity, and service quality are constant/fixed and unchanged, the variable of increasing member satisfaction has a shift of 3,050. 


\section{$A I \overline{I E B} \quad$ Annual International Conference \\ on Islamic Economics and Business, 2021}

b. The value of the regression coefficient X1 (location) is 0,149 , stating that for each addition of 1 unit to the $\mathrm{X} 1$ variable (location), it increases the value of member satisfaction by 0,149 .

c. The coefficient value of X2 (diversity of products) is 0.094 , which states that for each addition of 1 unit to the variable X2 (diversity of products), it increases the value of member satisfaction by 0,094 .

d. The value of the coefficient of determination X3 (quality of service) of 0,545 states that for every addition of 1 unit to the variable X3 (quality of service), the value of member satisfaction increases by 0,545 .

e. The sign (+) indicates the direction of the unidirectional relationship, while the sign (-) indicates the direction of the inversely proportional relationship between the independent variable $(\mathrm{X})$ and the dependent variable $(\mathrm{Y})$.

Table 10. BMT NUsantara UMAT MANDIRI Kalidawir Tulungagung Multiple Linear Regression Test Results

\section{Coefficients $^{\mathrm{a}}$}

\begin{tabular}{|c|c|c|c|c|c|c|}
\hline \multirow{2}{*}{\multicolumn{2}{|c|}{ Model }} & \multicolumn{2}{|c|}{$\begin{array}{l}\text { Unstandardized } \\
\text { Coefficients }\end{array}$} & \multirow{2}{*}{$\begin{array}{c}\text { Standardized } \\
\text { Coefficients }\end{array}$} & \multirow[b]{2}{*}{$t$} & \multirow[b]{2}{*}{ Sig. } \\
\hline & & B & Std. Error & & & \\
\hline \multirow[t]{4}{*}{1} & (Constant) & 6.318 & 2.638 & & 2.395 & .019 \\
\hline & LOKASI & .204 & .072 & .237 & 2.834 & .006 \\
\hline & $\begin{array}{l}\text { KERAGAMAN } \\
\text { PRODUK }\end{array}$ & .219 & .031 & .580 & 6.962 & .000 \\
\hline & $\begin{array}{l}\text { KUALITAS } \\
\text { PELAYANAN }\end{array}$ & .156 & .078 & .167 & 2.000 & .049 \\
\hline
\end{tabular}

a. Dependent Variable: KEPUASAN

\section{ANGGOTA}

Source: SPSS 23 results data, 2021

In this study, the multiple linear regression equation from the regression results obtained is as follows:

$\mathrm{Y}=6,318+0,204 \mathrm{X} 1+0,219 \mathrm{X} 2+0,156 \mathrm{X} 3$

Based on the above equation it can be concluded that:

a. The value of a (constant) of 6,318 states that if the variables of location, product diversity, and service quality are constant/fixed and do not change, the variable of increasing member satisfaction has a shift of 6,318.

b. The value of the regression coefficient X1 (location) is 0,204, stating that for each addition of 1 unit to the $\mathrm{X} 1$ variable (location), it increases the value of member satisfaction by 0,204 .

c. The coefficient value of X2 (diversity of products) is 0,219 , stating that for every addition of 1 unit to the variable X2 (diversity of products), it increases the value of member satisfaction by 0,219 .

d. The value of the coefficient of determination X3 (quality of service) of 0,156 states that for every addition of 1 unit to the variable X3 (quality of service), the value of member satisfaction increases by 0,156 .

e. The sign (+) indicates the direction of the unidirectional relationship, while the sign (-) indicates the direction of the inversely proportional relationship between the independent variable $(\mathrm{X})$ and the dependent variable $(\mathrm{Y})$. 


\subsection{Hypothesis Test}

\subsection{1. $\quad$ t Test (Partial Test)}

Table 11. BMT Muamalah Kutoanyar Tulungagung t Test Results

Coefficients $^{\mathrm{a}}$

\begin{tabular}{|c|c|c|c|c|c|c|}
\hline & & \multicolumn{2}{|c|}{$\begin{array}{l}\text { Unstandardized } \\
\text { Coefficients }\end{array}$} & $\begin{array}{c}\text { Standardized } \\
\text { Coefficients } \\
\end{array}$ & \multirow[b]{2}{*}{$t$} & \multirow[b]{2}{*}{ Sig. } \\
\hline \multicolumn{2}{|c|}{ Model } & B & Std. Error & Beta & & \\
\hline \multirow[t]{4}{*}{1} & (Constant) & 3.050 & 2.377 & & 1.284 & .202 \\
\hline & LOKASI & .149 & .072 & .154 & 2.068 & .041 \\
\hline & $\begin{array}{l}\text { KERAGAMAN } \\
\text { PRODUK }\end{array}$ & .094 & .042 & .166 & 2.223 & .029 \\
\hline & $\begin{array}{l}\text { KUALITAS } \\
\text { PELAYANAN }\end{array}$ & .545 & .062 & .661 & 8.847 & .000 \\
\hline
\end{tabular}

a. Dependent Variable: KEPUASAN

\section{ANGGOTA}

Source: SPSS 23 results data, 2021

Based on the table above, it can be concluded that:

1) Hypothesis 1 which reads: location has a positive and significant effect on member satisfaction.

From the table above, it shows that the tcount value is 2,068 while the ttable value is 1,98552 which is smaller than tcount. And the significance value is smaller than the significance level of $5 \%(0,05)$ which is indicated by the significance value for the location of 0,041 which is smaller than 0,05 . This means that location has a positive and significant effect on member satisfaction or in other words $\mathrm{H} 1$ is accepted. So it can be concluded that if the location variable increases, the member satisfaction variable also increases with the provision that other variables have a fixed value, and vice versa.

2) Hypothesis 2 which reads: product diversity has a positive and significant effect on member satisfaction.

From the table above, it shows that the tcount value is 2,223 while the ttable value is 1,98552 which is smaller than tcount. And the significance value is smaller than the significance level of $5 \%(0,05)$ which is indicated by the significance value for product diversity 0,029 which is smaller than 0,05 . This means that product diversity has a positive and significant effect on member satisfaction or in other words $\mathrm{H} 2$ is accepted. So it can be concluded that if the product diversity variable increases, the member satisfaction variable also increases, provided that other variables have a fixed value, and vice versa.

3) Hypothesis 3 which reads: service quality has a positive and significant effect on member satisfaction.

From the table above, it shows that the tcount value is 8,847 while the table value is 1,98552 which is smaller than tcount. And the significance value is smaller than the significance level of $5 \%(0,05)$ which is indicated by the significance value for service quality 0,000 less than 0,05 . This means that service quality has a positive and significant effect on member satisfaction or in other words $\mathrm{H} 3$ is accepted. So it can be concluded that if the service quality variable increases, the member satisfaction variable also increases, provided that other variables have a fixed value, and vice versa. 
Table 12. BMT NUsantara UMAT MANDIRI Kalidawir Tulungagung t Test Results

Coefficients $^{\mathrm{a}}$

\begin{tabular}{|c|c|c|c|c|c|c|}
\hline \multirow{2}{*}{\multicolumn{2}{|c|}{ Model }} & \multicolumn{2}{|c|}{$\begin{array}{l}\text { Unstandardized } \\
\text { Coefficients }\end{array}$} & $\begin{array}{c}\text { Standardized } \\
\text { Coefficients }\end{array}$ & \multirow[b]{2}{*}{$\mathrm{t}$} & \multirow[b]{2}{*}{ Sig. } \\
\hline & & B & Std. Error & Beta & & \\
\hline \multirow[t]{4}{*}{1} & (Constant) & 6.318 & 2.638 & & 2.395 & .019 \\
\hline & LOKASI & .204 & .072 & .237 & 2.834 & .006 \\
\hline & $\begin{array}{l}\text { KERAGAMAN } \\
\text { PRODUK }\end{array}$ & .219 & .031 & .580 & 6.962 & .000 \\
\hline & $\begin{array}{l}\text { KUALITAS } \\
\text { PELAYANAN }\end{array}$ & .156 & .078 & .167 & 2.000 & .049 \\
\hline
\end{tabular}

a. Dependent Variable: KEPUASAN

ANGGOTA

Source: SPSS 23 results data, 2021

Based on the table above, it can be concluded that:

1) Hypothesis 1 which reads: location has a positive and significant effect on member satisfaction.

From the table above, it shows that the tcount value is 2,834 while the ttable value is 1,98827 which is smaller than tcount. And the significance value is smaller than the significance level of $5 \%(0,05)$ which is indicated by the significance value for the location of 0,006 which is smaller than 0,05 . This means that location has a positive and significant effect on member satisfaction or in other words $\mathrm{H} 1$ is accepted. So it can be concluded that if the location variable increases, the member satisfaction variable also increases with the provision that other variables have a fixed value, and vice versa.

2) Hypothesis 2 which reads: product diversity has a positive and significant effect on member satisfaction.

From the table above, it shows that the tcount value is 6,962 while the ttable value is 1,98827 which is smaller than tcount. And the significance value is smaller than the significance level of $5 \%(0,05)$ which is indicated by the significance value for product diversity 0,000 less than 0,05 . This means that product diversity has a positive and significant effect on member satisfaction or in other words $\mathrm{H} 2$ is accepted. So it can be concluded that if the product diversity variable increases, the member satisfaction variable also increases, provided that other variables have a fixed value, and vice versa.

3) Hypothesis 3 which reads: service quality has a positive and significant effect on member satisfaction.

From the table above, it shows that the tcount value is 2,000 while the table value is 1,98827 which is smaller than tcount. And the significance value is smaller than the significance level of $5 \%(0.05)$ which is indicated by the significance value for service quality 0,049 which is smaller than 0,05 . This means that service quality has a positive and significant effect on member satisfaction or in other words $\mathrm{H} 3$ is accepted. So it can be concluded that if the service quality variable increases, the member satisfaction variable also increases, provided that other variables have a fixed value, and vice versa. 


\subsection{2. $\quad$ F Test (Simultaneous Test)}

Table 13. BMT Muamalah Kutoanyar Tulungagung F Test Results

ANOVA $^{\text {b }}$

\begin{tabular}{|l|r|r|r|r|c|}
\hline Model & Sum of Squares & df & Mean Square & $\mathrm{F}$ & Sig. \\
\hline 1 Regression & 206.903 & 3 & 68.968 & 29.518 & $.000^{\mathrm{a}}$ \\
Residual & 219.628 & 94 & 2.336 & & \\
Total & 426.531 & 97 & & & \\
\hline
\end{tabular}

a. Predictors: (Constant), KUALITAS PELAYANAN, LOKASI, KERAGAMAN PRODUK

b. Dependent Variable: KEPUASAN ANGGOTA

Source: SPSS 23 results data, 2021

From the table above, it shows that the results of the $\mathrm{F}$ test calculation obtained the Fcount value of 29,518 with a significant value of $0,000(<0,05)$. While the value of Ftable is 2,700, this means the value of Fcount $(29,518)>$ Ftable $(2,700)$. This means that the hypothesis is accepted that the location, product diversity, and service quality simultaneously or jointly have a significant effect on member satisfaction.

Table 14. BMT NUsantara UMAT MANDIRI Kalidawir Tulungagung F Test Results ANOVA $^{\mathrm{b}}$

\begin{tabular}{|l|r|r|r|r|r|}
\hline Model & Sum of Squares & df & Mean Square & $\mathrm{F}$ & Sig. \\
\hline 1 Regression & 95.865 & 3 & 31.955 & 19.744 & $.000^{\mathrm{a}}$ \\
Residual & 137.573 & 85 & 1.619 & & \\
Total & 233.438 & 88 & & & \\
\hline
\end{tabular}

a. Predictors: (Constant), KUALITAS PELAYANAN, KERAGAMAN PRODUK, LOKASI

b. Dependent Variable: KEPUASAN ANGGOTA

Source: SPSS 23 results data, 2021

From the table above, it shows that the results of the $\mathrm{F}$ test calculation obtained the Fcount value of 19,744 with a significant value of $0,000(<0,05)$. While the Ftable value is 2,710, this means the Fcount value $(19,744)>$ Ftable $(2,710)$. This means that the hypothesis is accepted that the location, product diversity, and service quality simultaneously or jointly have a significant effect on member satisfaction.

\subsection{Coefficient Determination $\left(\mathbf{R}^{2}\right)$}

Table 15. BMT Muamalah Kutoanyar Tulungagung Coefficient Determination Test Results

Model Summary ${ }^{b}$

\begin{tabular}{|l|r|r|r|r|}
\hline Model & $\mathrm{R}$ & $\mathrm{R}$ Square & \multicolumn{1}{c|}{$\begin{array}{c}\text { Adjusted R } \\
\text { Square }\end{array}$} & $\begin{array}{c}\text { Std. Error of the } \\
\text { Estimate }\end{array}$ \\
\hline 1 & $.696 \mathrm{a}$ & .485 & .469 & 1.529 \\
\hline
\end{tabular}

a. Predictors: (Constant), KUALITAS PELAYANAN, LOKASI, KERAGAMAN PRODUK

b. Dependent Variable: KEPUASAN ANGGOTA

Source: SPSS 23 results data, 2021

The table above shows that the statistical model summary table shows that the correlation coefficient (R) is 0,696 and the coefficient of determination (Adjusted R Square) is 0,469. It 


\section{$A I \overline{C F B} \quad$ Annual International Conference \\ on Islamic Economics and Business, 2021}

can be interpreted that the member satisfaction variable (Y) which can be explained by the independent variable location (X1) and product diversity (X2) and service quality (X3) is $0,469(46,9 \%)$. So, the independent variable is able to explain the dependent variable by $46,9 \%$, while the remaining $53,1 \%$ is explained by other variables not included in this study.

Table 16. BMT NUsantara UMAT MANDIRI Kalidawir Tulungagung Coefficient Determination Test Results

\begin{tabular}{|l|r|r|r|c|}
\hline Model & $\mathrm{R}$ & $\mathrm{R}$ Square & $\begin{array}{c}\text { Adjusted R } \\
\text { Square }\end{array}$ & $\begin{array}{c}\text { Std. Error of the } \\
\text { Estimate }\end{array}$ \\
\hline 1 & $.641^{\mathrm{a}}$ & .411 & .390 & 1.272 \\
\hline
\end{tabular}
a. Predictors: (Constant), KUALITAS PELAYANAN, KERAGAMAN
PRODUK, LOKASI

b. Dependent Variable: KEPUASAN ANGGOTA

Source: SPSS 23 results data, 2021

The table above shows that the statistical model summary table shows that the correlation coefficient $(\mathrm{R})$ is 0,641 and the coefficient of determination (Adjusted R Square) is 0,390. It can be interpreted that the member satisfaction variable (Y) which can be explained by the independent variable location (X1) and product diversity (X2) and service quality (X3) is $0,390(39 \%)$. So, the independent variable is able to explain the dependent variable by $39 \%$, while the remaining $61 \%$ is explained by other variables not included in this study.

\section{Conclusions}

Location has a positive and significant impact on member satisfaction at BMT Muamalah Kutoanyar Tulungagung and BMT NUsantara MANDIRI UMAT Kalidawir Tulungagung. This means that the better or strategic location of BMT, the satisfaction of members will also increase. This is because the location of BMT Muamalah Kutoanyar Tulungagung is easily accessible by means of transportation and the location of BMT NUsantara UMAT MANDIRI is close to public facilities, such as gas stations and traditional markets.

Product diversity has a positive and significant impact on member satisfaction at BMT Muamalah Kutoanyar Tulungagung and BMT NUsantara UMAT MANDIRI Kalidawir Tulungagung. This means that the better the variety of products provided by BMT, the greater the satisfaction of members. This is because the BMT Muamalah Kutoanyar Tulungagung product is felt to be able to help improve the economy of the community around the BMT and the products that exist in the BMT NUsantara UMAT MANDIRI are different from other BMT products and are able to compete, such as ijarah products and hajj bailouts which are different from other BMT products and Of course they can compete.

Service quality has a positive and significant impact on member satisfaction at BMT Muamalah Kutoanyar Tulungagung and BMT NUsantara MANDIRI UMAT Kalidawir Tulungagung. This means that the better the quality of services provided by BMT, the satisfaction of members will also increase. This is because BMT Muamalah Kutoanyar Tulungagung and BMT NUsantara UMAT MANDIRI Kalidawir Tulungagung guarantee the confidentiality of data and security of funds for their members and employees of BMT NUsantara MANDIRI UMAT Kalidawir Tulungagung who look neat and polite. So get a positive response from the members.

Location, product diversity, and service quality together have a positive and significant effect on member satisfaction at BMT Muamalah Kutoanyar Tulungagung and BMT NUsantara MANDIRI UMAT Kalidawir Tulungagung. This means that the better the 
location, product diversity, and service quality together or simultaneously, the satisfaction of members will also increase. This is due to the fact that occurred in the field that the location of BMT Muamalah Kutoanyar Tulungagung is easily accessible by means of transportation and BMT NUsantara UMAT MANDIRI Kalidawir Tulungagung is close to public facilities. The products of BMT Muamalah Kutoanyar Tulungagung are also considered to be able to help improve the economy of the community and BMT NUsantara UMAT MANDIRI Kalidawir Tulungagung which is able to provide products that are different from other BMT products and are able to compete. And supported by employees of BMT NUsantara UMAT MANDIRI Kalidawir Tulungagung who look neat, polite and both BMTs are able to guarantee the confidentiality of data and security of member funds. So that it can affect the satisfaction of members in BMT Muamalah Kutoanyar Tulungagung and BMT NUsantara UMAT MANDIRI Kalidawir Tulungagung.

\section{References}

Indrasari, Meithiana. 2019. Pemasaran dan Kepuasan Pelanggan. Surabaya: Unitomo Press.

Kasmir. 2005. Pemasaran Bank. Jakarta: Kencana.

Lupiyoadi, Rambat. 2001. Manajemen Pemasaran Jasa Teori dan Praktik. Jakarta: Salemba Empat.

Mawarni, Iga. 2018. Pengaruh Kualitas Produk, Kualitas Pelayanan, dan Harga Terhadap Kepuasan Pelanggan Pada RSUD dr. R. Soetrasno Rembang. Semarang: Skripsi.

Mulyaningsih, Luh Ayu dan I Gusti Agung Ketut Gede Suasana. 2016. "Pengaruh Kualitas Layanan dan Citra Perusahaan Terhadap Kepuasan Nasabah Pada Bank OCBC NISP di Denpasar". Jurnal Manajemen, Vol. 5 No. 1.

Nasution, M. Nur. 2005. Manajemen Mutu Terpadu (Total Quality Management), Edisi Kedua. Bogor Selatan: Ghalia Indonesia.

Oetama, Seanewati dan Desy Herlina Sari. 2017. "Pengaruh Fasilitas Dan Kualitas

Pelayanan Terhadap Kepuasan Nasabah Pada PT Bank Mandiri (PERSERO)

Tbk. di Sampit”. Jurnal Terapan Manajemen dan Bisnis, Vol. 3 No. 1.

Ridwan, Muhammad. 2004. Manajemen Baitul Maal wa Tamwil (BMT). Yogyakarta: UII Press.

Risal, Taufiq. 2019. "Pengaruh Kualitas Pelayanan Terhadap Loyalitas Nasabah Dengan Kepuasan Sebagai Variabel Intervening Pada BMT Kampoeng Syariah”. Jurnal Manajemen dan Bisnis, Vol. 1 No. 1.

Rohmawati, Zunita. 2018. "Kualitas, Harga, dan Keragaman Produk Terhadap Loyalitas Pelanggan”. Jurnal Riset Entrepreneurship, Vol. 1, No. 2.

Rumastari, Rizka Putri dan Aris Sunindyo. 2019. “Analisis Pengaruh Kualitas Pelayanan, Produk, Harga, Dan Lokasi Terhadap Kepuasan Nasabah (Studi Kasus Pada PT

Bank Rakyat Indonesia (PERSERO) Tbk. Unit Ngesrep Semarang) ”. Jurnal Keuangan dan Bisnis, Vol. 7, No. 2.

Sari, Lidia Kurnia dan Euis Soliha. 2018. "Kualitas Layanan, Persepsi Tingkat Suku Bunga

Dan Lokasi Terhadap Kepuasan Nasabah”. Jurnal Porsiding Sendi_U.

Setiawan, Heri dkk. 2016. "Pengaruh Kualitas Produk, Kualitas Pelayanan Dā̄ Kepercayaan Terhadap Kepuasan Nasabah Dan Loyalitas Nasabah Dengan Kepuasan Sebagai Variabel Intervening (Studi Kasus Pada Nasabah Koperasi Rejo Agung Sukses Cabang Ngaliyan). Journal of Management, Vol. 2 No. 2. Sondakh, Conny. 2014. "Kualitas Layanan, Citra Merek Dan Pengaruhnya Terhadap Kepuasan Nasabah Dan Loyalitas Nasabah Tabungan (Studi Pada Nasabah 


\section{$A T C$ Annual International Conference \\ on Islamic Economics and Business, 2021}

Taplus BNI Cabang Manado)". Jurnal Riset Bisnis dan Manajemen, Vol. 3, No. 1.

Tjiptono, Fandy. 2007. Pemasaran Jasa. Jawa Timur: BayuMedia Publishing. 2011. Pemasaran Jasa. Yogyakarta: Bayumedia Publishing.

Wahab, Wirdayani. 2017. "Pengaruh Kualitas Pelayanan Terhadap Kepuasan Nasabah Industri Perbankan Syariah di Kota Pekanbaru”. Jurnal Kajian Ekonomi Islam, Vol. 2, No. 1. 